Communication

\title{
Teaching and Learning English Language in Nigerian Schools: Importance and Challenges
}

\author{
Hamisu Abubakar Muhammad ${ }^{1}$, Sani Ya'u ${ }^{1,2}$, Umma Isah Aliyu ${ }^{1}$, Maryam Hassan ${ }^{3,}$ * \\ ${ }^{1}$ Child Development Centre, Sa'adatu Rimi College of Education, Kumbotso, Nigeria \\ ${ }^{2}$ Consultancy Unit, Sa'adatu Rimi College of Education, Kumbotso, Nigeria \\ ${ }^{3}$ Department of English, School of Languages, Sa'adatu Rimi College of Education, Kumbotso, Nigeria
}

Email address:

maryamhassan.mh $a$ gmail.com (M. Hassan)

${ }^{*}$ Corresponding author

\section{To cite this article:}

Hamisu Abubakar Muhammad, Sani Ya'u, Umma Isah Aliyu, Maryam Hassan. Teaching and Learning English Language in Nigerian Schools: Importance and Challenges. Teacher Education and Curriculum Studies. Vol. 3, No. 1, 2018, pp. 10-13. doi: 10.11648/j.tecs.20180301.13

Received: May 1, 2018; Accepted: June 6, 2018; Published: June 25, 2018

\begin{abstract}
The importance of English language cannot be overemphasized, due to its role in social, political economical, and environmental development. English language functions as a vehicle of interaction and an instrument of communication. This paper discussed the importance of English language as official language of communication in Nigeria. The paper tries to highlight the challenges of teaching and learning English language in Nigerian schools. The paper also, discusses useful strategies the teachers and learners of English language in Nigerian schools may adopt so that teaching and learning of English would be simple.
\end{abstract}

Keywords: Communication, Challenges, English, Importance, Nigeria

\section{Introduction}

English language is an official language in Nigeria and whatever you want to do you have to communicate in English [1]. As a result of this you cannot escape English language throughout your lives in your carrier of choice. If you want to study engineering, medicine, accounting, economics as well as other formal disciplines in the university English language is compulsory as a pre-requisite for entering into the university [1]. English and the use of English is compulsory in JAMB for all candidates seeking admissions into the universities [1]. Evue [2] opined that, one of the reasons why English is so central to Nigeria's educational growth is because of its significant role as a medium of knowledge delivery in Nigerian schools. English is the language of instruction in schools particularly the upper level of primary school, secondary school and beyond [2]. English is one language that has travelled round the world and now has almost as many speakers as its native speakers; a feat that is unparalleled in the history of any language in the world. That is not all, the language is increasingly growing in strengths, pushing other world languages backward in the global space, opening new frontiers.

Owolabi amd Nnaji [3] stated that, English is an irrestible language as far as development is concerned because "for any nation particularly in the 3rd world to be relevant and derive the maximum benefit from the opportunities that abound in every area of human need, for personal advancement and national development, English is a sine qua non". This is why English continues to hold sway as the language of development in most developing nations of the world, and even in some developed nations of Asia, where it is learnt and used as a foreign language [3].

English language is the Nigerian elite. Mastery of the language is the defining attribute of elite status since it correlates with other social makers such as post secondary or professional education, a good job and comfortable incomes that come with it. Also, acquiring a mastery of English is one of the goals of those aspiring to elite status [2]. 


\section{Importance of Learning English Language}

The importance of communication (English) to man is incalculable, especially when daily human interaction is considered. In political and social policy, English language functions as a vehicle of interaction and an instrument of communication with the use of communications, although it has always possessed an added cultural importance as a tool of the dominant ideology [4]. Language is a powerful tool of control used by the colonial powers. According to Danladi [4] English language plays a crucial role in the social, political and economic life support of the people in a given geographic entity. In spite of all perceived roles of English language to humankind, an all-embracing interpretation of its continues to elude us due to the complexity of its structure and the functions it performs. According to Olusoji [5] English language contributes immensely to the rapid growth and development experienced in Nigeria. Salahuddin et al., [6] stated that, English is the dominant language of international business and economic development, and that dominance continues to grow with the continued globalization of business through mergers and international investment.

\section{Challenges of Teaching and Learning English Language}

English is not a subject which can be taught; it is a subject which must be learnt. English language teaching is regarded as being far from satisfactory in the country, not conducive in learning the language. Teaching and learning the English is based on the system of grammatical patterns and there is a trend of formal and bookish language, students just produce sentence and focus on reading and writing [7]. The weakness of English language learners in general has been attributed to various factors: lack of knowledge on the part of school graduates when they join the university, school and English language department curricula, teaching methodology, lack of the target language environment and the learners' motivation as well as others [8].

\subsection{Learner's Perspective}

Learners of English encounter problems in both speaking and writing. There are a lot of problems that confront students in their course of studying English language. It was reported that, most English instructors and university officials complained about the continuous deterioration of the mastery in the English language among the students [8].

\subsection{Teacher's Attitudes}

Most observations of researchers confirmed that teachers usually count on the personal interest of their students to learn. In some cases this practice might work as this could inculcate in the minds of the students the value of independence or self-reliance, but in some cases it would hamper the academic development of the students. Another observation is that teachers do not usually follow up the work of their students, to check whether they have improved or not [8].

\subsection{Lack of Repetition and Frequent Practice}

Most students are not interested in learning English language, so they will be tired of repeating and practicing the language. Also, students who attend English classes outside of school, have higher academic level than others and listening to repetitive low-level content for them is unattractive and boring [9].

\subsection{Lack of Students Concentration}

Another factor is lack of concentration of students in the classroom. When students do not have concentration, teaching and learning can't be effective. Concentration depends on these factors: fatigue and insomnia, environment and family problems [9].

\subsection{Language Differences}

Akujobi and Chukwu [10] asserted that, second language learners experience overwhelming challenges in learning the second language and these challenges are due to the differences between the forms and meaning of English and those of the native language.

\subsection{Language Transfer}

Language transfer gives rise to interlingual errors which are based on the interference theory. The transfer of learner's first language patterns into those of the second language constitutes one of the bases for interlingual interference. When this transfer has a negative effect on the second language, then the problems result.

\subsection{Lack of Students Interest}

Most students are not interested in learning the language and just think about passing the course, thus because they are not interested, they do not listen to their teacher and do not learn anything, even if they learn something they will forget it quickly, because they are tired of its repetition.

\subsection{Disunity and Insecurity}

Aremu [11] reported that disunity and insecurity in Nigeria has led to the formation of different ethnic militants among which are; Maitatsine fundamentalists, the boko haram and Zango-Kataf in northern Nigeria, Oodua progressive congress in Yoruba land, Egbesu in the defence of biafra, Movement for the emancipation of Niger Delta (MEND) as well as other militants group in the country. These problems of disunity and insecurity play a significant role in dwindling the teaching and learning English language in Nigeria. 


\section{Solutions to Challenges of Teaching and Learning English Language in Nigeria}

Several attempts were made by different scholars of linguistics and literature in regard to solution to teaching and learning English subject in Nigerian schools. The following may serves as the solution to the reported challenges in this article; effort should be made to promote speaking, listening, reading and writing of English language in the classroom. Teachers should make a reasonable effort to encourage students to use English as medium of communication not only in the classroom but also at home as well. Teachers should try to learn and use modern methods of teaching including communicative method in the classroom. Teachers should emphasize both on audio and visual aids and modern methods of teaching during the teaching of English. English teacher should encourage the students to learn the language by repeating. This encouragement should not be verbalized, but some awards should be considered to increase the motivation and interest in students. Students should be encouraged to repeat the language, because the language can be learned only be repetition. Students are advised to use English language in the classroom as well as at home so that they can get good practice. Teachers need to improve their knowledge of English language because accurate knowledge is important for skills transfer [12]. There should be regular language professional development seminars for teachers of English language [12]. They should try to watch English programs when they get free time, specially listen to English speeches. If possible students should try to use internet for learning English. Curriculum should be reviewed after some specific time. All the stakeholders, including students, teachers, parents and administrators should be included in the committee for reviewing the curriculum. Curriculum should be child centered and activity based which could promote English as language not as subject. Curriculum should be based on modern teaching methodologies. Teachers should be trained keeping in view the changes made in the curriculum. More creative exercises based on four skills (speaking, listening, reading and writing) should be included in the text book of English. Parents should encourage their children to use English at home and class. they should also try to buy their children different English books and magazines especially English newspapers and make sure that children read them on the regular basis. Parents should also make sure that their children attend their classes regularly. They should also have close contact with the teacher so that, they can inquire about the study and class performance of their children. The administrators should try to motivate teachers for attending the classes regularly and make use of English language in the class. They should try to provide required facilities in the schools. They should try to provide professional assistance to the teachers. Teachers use audio-visual aids and modern methods of teaching during the teaching of English. There is also the need to establish balance in the content of teacher education. Balance in terms of academic and professional content of the Teacher Education Programme (TEP). Relevance is also another issue. The content of the TEP should be made to be relevant to the emerging needs and challenges of the 21st century [13]. Selection of suitably qualified candidate is a crucial factor in teacher's preparation programme that must not be ignored if Nigeria is committed to ensuring the quality and effectiveness of teacher education institutions. If the foundation is weak, the final output will equally be weak [13]. There is still a general belief that anyone can teach anything. The authority concerned especially the Teacher Registration Council (TRC) should do all it can to professionalize teaching [13].

\section{Conclusion}

The importance of English language cannot be overemphasized, due to its role in social, political economical, and environmental development. There are many challenges that teachers and the learners face in teaching and learning English in Nigerian schools. Both the teachers and learners have role to play in overcoming this situations.

\section{References}

[1] Oribabor O. A. (2014). The problems and prospects of teaching of English language in Ife central local government of Osun state. Journal of Literature, Languages and Linguistics, 4: 70-72.

[2] Evue A. O. (2013). Challenges facing the teaching of English language in secondary schools in Aniocha south local government area of Delta state Nigeria. African Education Indices, 5 (1).

[3] Owolabi D. and Nnaji C. I. (2013). The English language and the mass media as tools for sustainable development in multilingual nations. International Journal of language and linguistics, 1 (4): 124-130.

[4] Danladi S. S. (2013). Language policy: Nigeria and the role of English language in the 2 st century. European Scientific Journal, 9 (17).

[5] Olusoji O. A. (2012). Effects of English language on National Development. Greener Journal of Social Sciences, 2 (4): 134-139.

[6] Salahuddin A. N. M., Khan M. R. and Rahman A. (2012). Challenges of implementing English curriculum at rural primary schools of Bangladesh. The International Journal of social science, 7 (1): 34-51.

[7] Teevno R. A. (2011). Challenges in teaching and learning of English at secondary level class X. International Journal of Human Resource Studies, 1 (2): 27-35.

[8] Khan I. A. (2011). Challenges of teaching/learning and management. Global Journal of Human Social Science, 11 (8): 68-80.

[9] Khajloo A. I. (2013). Problems in Teaching and Learning English for Students. International Journal of engineering, research and development, 7 (3): 56-58. 
[10] Akujobi O. S. and Chukwu E. (2012). Challenges of effective English language learning in Nigerian secondary schools. International Journal of Arts and Humanities, 1 (4): 57-68.

[11] Aremu M. A. (2014). Impacts of the use of ICT in English language pedagogy on Nigeria's National Development. International Journal of English language and linguistics research, 2 (1): 56-67.
[12] Nwanyanwu A. U. (2017). Effective teaching of the English language in multicultural L2 classrooms: The Nigerian perspective. International Journal of English Language Teaching, 5 (4): 26-36.

[13] Odey E. O. and Effiong A. A. (2012). The Challenges of Curriculum Implementation in Nigeria Teacher Education. Journal of Education and Practice, 3 (15): 127-131. 